\title{
FINDING A FAIR LAND DISPUTE SETTLEMENT MECHANISM BETWEEN ADAT LAW COMMUNITY VS. INVESTOR
}

\author{
Ratih Lestarini* \\ * Department of Law and Society, Faculty of Law Universitas Indonesia \\ Article Info \\ Received : 25 June 2016 | Received in revised form : 18 November 2016 | Accepted : 25 November 2016 \\ Corresponding author's e-mail : ratihlestarini@yahoo.com
}

\begin{abstract}
Land utilization for investment in local areas raises various land related problems that ends with conflicts within the community. A conflict that occurs, usually begins with the management of communal land "tanah ulayat" within the adat law community environment, and in this case, land utilization that is managed by the third party (investors). The basic problem is the difference of perception and expectations toward the company that exists in the land which is claimed by the community. Both parties have their own claim on the land based on each legal systems, in this situation adat law or local law faced with state law which is used by investors. So far, the Indonesian government has yet to have legal grounds in giving a directions for land dispute/ conflict settlement mechanism. This paper attempts to give an input regarding a land dispute settlement mechanism that can be accepted for all disputing parties. The paper features critical analysis using legal pluralism approach towards related government policies and technical regulations in the ministerial level. These regulations, among others are, Minister of Agrarian Regulation No. 5 of 1999 and Ministry of Agrarian and Spatial Affairs Regulation No. 9 of 2015, also the draft of Law regarding Recognition and Protection of Adat Law Community.
\end{abstract}

Keywords: adat law, communal land rights, ulayat, dispute settlement

\begin{abstract}
Abstrak
Perambahan tanah untuk investasi di daerah menimbulkan berbagai persoalan tanah yang berujung pada konflik tanah di antara masyarakat. Konflik terjadi, biasanya terkait dengan pengelolaan tanah ulayat dalam lingkungan masyarakat Adat, dalam hal ini pemanfaatan tanah dikuasai oleh pihak ketiga (investor/penanam modal). Persoalan mendasar adalah adanya perbedaan persepsi serta harapan masyarakat tentang keberadaan perusahaan di tanah yang diklaim merupakan tanah mereka. Kedua pihak mempunyai klaim atas tanahnya berdasarkan sistem hukum masing-masing, dalam situasi ini hukum lokal atau Hukum Adat berhadapan dengan Hukum Negara seperti yang digunakan oleh para investor. Sementara ini, Pemerintah belum mempunyai payung hukum dalam memberikan pedoman mekanisme penyelesaian sengketa/konflik tanah dimaksud. Tulisan ini hendak mencoba untuk memberikan masukan terkait dengan bentuk mekanisme penyelesaian sengketa yang dapat diterima oleh semua pihak melalui analisis kritis dengan pendekatan pluralisme hukum terhadap kebijakan Pemerintah Peraturan teknis di tingkat kementrian, seperti Peraturan Menteri Agraria /Ka BPN No. 5 Tahun 1999 Peraturan Menteri Agraria Dan Tata Ruang/kepala Badan Pertanahan Nasional No.9 Tahun 2015 dan juga RUU Pengakuan dan Perlindungan Masyarakat Hukum Adat.
\end{abstract}

Kata kunci: hukum adat, tanah ulayat, hak ulayat, penyelesaian sengketa 


\section{INTRODUCTION}

The growing development of plantation, agriculture, or other industries, exercised by the government or private sectors in the region, has increased the demands on land utilization. Based on the data issued by the chairman of the Indonesian Association of the Industrial Area (HKI), Hendra Lesmana, land demands for the industrial sector in the past two years continue to rise. For the average, the demand of the industrial land has reached 1.000 hectares annually. ${ }^{1}$ The Ministry of Industry estimated that until 2019, the need for the industrial area is around 3.353 hectares of land. The numbers have not been calculated with the demands for infrastructure; if combined, the land demands are estimated around 4.970 hectares. In the long term (2013-2015), it has been estimated that the demand for land has become 50.216,27 hectares. ${ }^{2}$ From the projection above, 60 percent of the land demands are situated in the Java Island, and the remain spread outside of the Java Island. ${ }^{3}$

Meanwhile, in the agricuture sector, the Ministry of Agriculture has issued a policy to solve the increasing demands of agricutural land with land clearing. For the period of 2010 - 2014, an area of 347.984 hectares have been cleared for agricultural use. This policy is taken with the consideration that annually around $50.000-100.000$ hectares of agricultural land shifted its function to non-agriculture land. The land clearning policy is intended so that the remaining agricultural land can be expanded. 4 Data above shows the need for land for investment activities on a large scale, and the activities have boosted the land utilization deeper into the rural area where communal adat land rights still exist.

Land clearning in the rural area inflicts various land issues that end with land disputes or conflicts between communities. Conflicts that usually occur are related to the management of communal land rights (tanah ulayat) within the environment of the adat law community, it has then shifted to land utilizations tenured by the third party (investors). Temporary data collected by the Indonesian Land Agency (BPN) estimated that until 2013, land disputes in Indonesia has reached 12.000 cases. $^{5}$ Meanwhile, according to the data collected by BPN based on the 2011-2013 report, from around 4.000 land dispute, only $48 \%$ of them are settled. Traced by location,

1 Statement of the Chairman of Industrial Area Association (Himpunan Kawasan Industri), Hendra Lesmana in Rakyat Merdeka, "Kritis, Permintaan Lahan Industri 1.000 Ha Per Tahun [Critical, the Demands of Industrial Area Reached 1.000 hectare annualy]," http://www.kemenperin.go.id/artikel/4137/KritisPermintaan-Lahan-1.000-Ha-Per-Tahun, accessed 8 September 2015.

2 Statement of the Director General of Industrial Area Development, Ministry of Industry Republic of Indonesia in Dini Hariyanti, “2015-2019, Kebutuhan Lahan Kawasan Industri capai 3.353 hektar [2015-2019, Needs for Land for Industrial Area Reaches 3.353 hectare]”, http://industri.bisnis.com/ read/20140905/257/255383/2015-2019-kebutuhan-lahan-kawasan-industri-capai-3.353-hektar-, accessed 8 September 2015.

3 Investor Daily, "Kawasan Industri Butuh Lahan 10 Ribu Ha [Industrial Area Needs 10.000 hectares of Land]," http://www.kemenperin.go.id/artikel/4702/Kawasan-Industri-Butuh-Lahan-10-Ribu-Ha, accessed 8 September 2015

4 Ministry of Agriculture of the Republic of Indonesia, "Rencana Strategis Kementerian Pertanian tahun 2015-2019 [Strategic Action Plan of the Ministry of Agriculture 2015 - 2019]," http://www.pertanian.go.id/file/RENSTRA_2015-2019.pdf, accessed 3 February 2016. The transformation of agriculture to non-agriculture led to shrinking agricultural land, let alone in Banten province, every year 273 hectares of farmland disappeared.

5 Statement of the Head of National Land Agency of Indonesia, Henadarman Supanji in an event commemorating the National Agrarian Day, in Hadi Suprapto and Erik Hamzah, "Sengketa Tanah Mencapai 12 Ribu Kasus [Land Dispute Cases Reach 12 Thousand]," http://nasional.news.viva.co.id/news/ read/463821-sengketa-tanah-mencapai-12-ribu-kasus, accessed 12 March 2016. 
most of the case that occur are situated within the provinces that are known for high adat claim number and high population of farmers. ${ }^{6}$

Until now, the land dispute settlement mechanism often does not come up with expected results. Even after the case has been settled by the court, it does not always bring peace among the disputing parties. The adat law community have often become the losing party in these disputes. On the contrary, the investors also have to pay for the compensation multiple times, because investors could not fulfill all the compensation demands filed by the adat law community. Meanwhile, the said dispute settlement mechanism has yet to be regulated by the government; this causes the inability of land conflict cases to be settled in an effective and efficient manner, and because of that, the land conflict situation in Indonesia has become wider. In 2013, in order to address the situation of the conflicts, the government formulated the Draft Law on Recognition and Protection of Adat Law Community Rights (RUU Pengakuan dan Perlindungan Hak Masyarakat Hukum Adat, hereinafter referred to as "RUU PPHMHA"). The draft contains the regulation on the communal land dispute settlement mechanism through Adat Court based on Adat Law.

This paper attempts to give the inputs required related with the form of dispute settlement mechanism that can be accepted by all parties. The paper provides a critical analysis of dispute settlement regulation between the adat law community and the outside party - investors from both the government or private parties. Currently, the provision related to this issue is stipulated in the RUU PPMHA and several Ministerial Regulations, among others, the Ministry of Agrarian/Head of National Land Agency (BPN) Regulation No. 5 of 1999 on the Guidance for Dispute Settlement of Communal Land Rights, and Ministry of Agrarian and Spatial Affairs Regulation No. 9 of 2015 on Procedures of Appointment of Communal Land Rights for Adat Law Community and Communities Located in Certain Region. The fundamental issue is the different perceptions and community expectations for the companies that exist within the claimed land. Hence, it is necessary to find a better form of land dispute settlement mechanism, which could render a decision that embodies justice and legal certainty. The decision should achieve a balance between the protection of the interests of the adat law community on one side, and the investment certainty for investors on the other side.

In examining the issue of land conflicts and the settlement mechanism, this paper will be divided into several sections. Part one is the introduction that provides the background and significance of this study as well as the outline of this paper. The second part is the structure of the Indonesian society and legal pluralism. For this section, which will be discussed first, the structure of the Indonesian society to explain the structure of society that is diverse in terms of the level of culture and diversity of laws that govern them. The second sub-section, the cultural diversity of existing laws in the society will then be explained in the perspective of legal pluralism, especially in land law pluralism. This discussion is to show that the community have their own

6 Myrna A. Safitri, “Jalan Ketiga Menuju Keadilan: Berbagai Upaya Memperluas Akses Terhadap Keadilan Pegelolaan sumber daya Alam Dalam Pembauran Hukum Di Indonesia [The Third Way Towards Justice: Efforts Expanding Access to Justice Natural Resources Management In Law Reform in Indonesia]" (paper presented at the national seminar on Membangun Politik Hukum Sumber Daya Alam Berbasis Cita Hukum Indonesia [Building a Politics of Law of Natural Resources based on Rechtsidee of Indonesia], Semarang, Diponegoro University, 15 April 2015). Be informed that the above data do not describe the whole conflict over natural resources. This is because the BPN limited authority only on land outside the forest area. Ministry of Environment and Forestry stated there are 576 cases of conflicts in forest areas. 
adat law that governs communal land to be managed and exploited by members from one generation onto the next; however, in the structure of other societies, especially in urban areas, the utilization of their land is subject to state law. Problems arise when these two types of societies meet and confront each other with their respective laws. In the context of legal pluralism, this section will discuss questions related to the nature of pluralism on how it is associated with the relationship between state law and the adat law. The third subsection contains the discussion regarding the position of adat law within the Indonesian legal system. This needs to be addressed given the land conflict issues are derived from the position of adat law in the state legal system where the existence of adat law is recognized by the state law as long as the adat law is still alive; however, as long as the adat law society, including its territory, can not be recognized by the state (due to the necessary requirements that must be met, provided in state law for the recognition of adat law society), the communal region or the communal land becomes state land. Furthermore, in the fourth subsection, the author will discuss the social impacts of conditional recognition of the adat law for adat law societies in economic development. This section will explain the conditions when the adat law faces state law. Starting with the licensing/granting of land rights by the government to enterprises which then said agrarian concessions are claimed by the adat law society located in their territory. As a result, social unrest occurs in a society that can lead to widespread land conflicts.

The third part of this paper consists of three sub-sections. The first subsection will discuss the articles related to dispute settlement mechanism of adat disputes provided in the RUU PPHMA, and also on the same sub section, the author will give critics regarding the weakness regarding the substance of adat dispute resolution mechanism that are provided. Sub section two is about the recognition and protection of the rights of adat law society to land in the Agrarian Ministerial Regulation. In the context of the protection of the adat law society, this section features the discussion of two Agrarian Ministry Regulations (Permenag), namely, the Agrarian Minister/ Head of National Land Agency Regulation No. 5 of 1999 regarding Dispute Resolution Guidelines for Communal Land Rights of Adat Law Society and the Minister of Agrarian and Spatial Planning/Head of National Land Agency Regulation No. 9 of 2015 on Procedures for Establishing Communal Land Rights of Adat Law Society and Communities in Certain Regions. The second discussion will be necessary to see if this time, the government has provided dispute resolution mechanisms in order to provide protection and legal certainty for both parties, adat law society and investors, or not. The third sub-section is discusses about the alternative dispute settlement of communal land rights of adat law society: win-win solution for both parties (investor and adat law society). The discussion of this subsection features a suggestion for the government given that there are no guidelines for the settlement of land conflicts between adat law society and investors. The discussion begins with the current reality, where traditional justice is not effective in resolving land disputes, even in cases where the parties finally have to settle the case in hearings in two different forums. From the discussion of these conditions, the necessity for a different approach in the resolution of land disputes can be concluded. To that end, the author suggests the acceleration of the establishment of the Agrarian Court. Where regarding the process of hearing, the Agrarian Court judges should have knowledge not only in related legislations but also socio-legal aspects of the case, as it is necessary in order to reach a decision that is a win-win solution. The last is the fourth part that contains conclusions and suggestions. 


\section{STRUCTURE OF INDONESIAN SOCIETY AND LEGAL PLURALISM}

\section{A. Structure of Indonesian Society}

In general, the Indonesian society is a plural community consisting of various ethnicities, where each ethnic group has their own cultures that varies from one another. ${ }^{7}$ Based on the data published by the BPN, there are 350 ethnic groups in Indonesia. ${ }^{8}$ Each ethnic group has a different culture that varies from one another. The Indonesian society is divided into several groups that live in rural areas, villages, small towns, or large metropolitan areas with different standards of living and characteristics. Below is the illustration of the description of the Indonesian society structure with the law which governs them.

Figure 1: 9

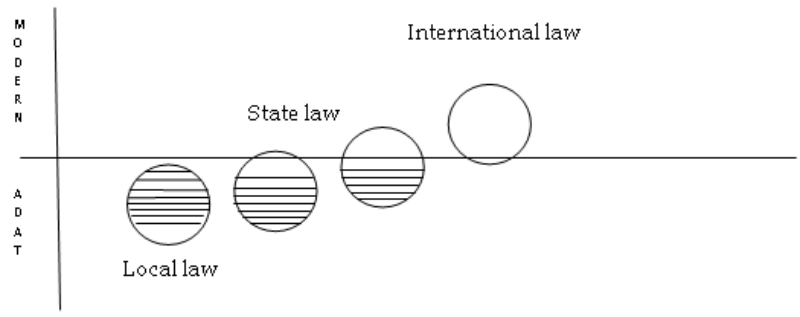

From the given figure above, it can be explained that:

Group 1 - a primordial culture society, is an isolated tribe that lives in a physically isolated area and are also culturally separated from outside world (also known as secluded tribes). Their whole life is guided by the magical force with certain characteristics: their economic system is based on forest product gathering or wild animal hunting (food collection and hunting). In relation with land utilization as their livelihood, they assume that all the lands utilized for living are common property and utilized together. Their way of life is based on the guidance of the spirits of their ancestors; hence, social control towards the behavior of members of the society is exercised by the spirits. As for the mechanism, the said guidance of the spirits is conveyed through natural phenomenons and through the medium of the chief of tribes or the cleric. ${ }^{10}$ This type of society can be found in tribes in secluded areas,

${ }^{7}$ Soerjono Soekanto dan Mustafa Abdullah, Sosiologi Hukum dalam Masyarakat [Sociology of Law in Society] (Jakarta: Rajawali Pers, 1987), p. 75. Ethnicities itself is actually a human entities are strongly bonded by awareness of the unity of the social system and culture, which is supported by specific language among the peoples.

8 Director of Spatial Planning and Land Affairs, Ministry of National Planning and Development/National Planning and Development Agency, "Kebijakan Nasional Penetapan Tanah Adat/Ulayat [National Policy on Decision of the Communal Land Rights" (paper presented at the workshop on Realisasi Hak Atas Tanah dan Rumah di daerah tertinggal [Realization of the Right to Land and Housing in underdeveloped areas], Jakarta, 15 January 2014).

9 Selo Soemarjan, "Modernisasi: Arti dan Konsepnya dalam Pembangunan Indonesia [Modernization: Its Meaning and the Concept in the Development of Indonesia]," in Pokok-Pokok Pikiran Selo Soemardjan, ed. Desiree Zuraida and Jufrina Rizal (Jakarta: Pustaka Sinar Harapan, 1993), p. 75.

10 Selo Soemarjan, "Pluralisme Budaya di Indonesia (Suatu Tinjauan Sosiologis) [Legal Pluralism in 
among others, tribes that still live in jungles, such as Anak Rimba tribe, Anak Dalam tribe in Sumatera, To Kajang tribe in Sulawesi, or secluded tribes in Papua.

The next, Group 2 - is a cuturally more developed society; its culture has advanced to the stage of traditional culture or adat society. In this stage of society, although they still believe in the spirits of their ancestors, they have developed their own confidence so that they can have contact with neighboring villages around the tribe. Other than that, they are able to form a customary law - adat law as their base of life. In other words, the socio-cultural institutions which function as the guidance for social interactions in the social structure and operation are determined by the custom that gets stronger over time, so that it develops into adat law. Adat law norm as a social control utility has a significant role to maintain peace, security, and prosperity; exercised by members of the society (not exercised by the spirits, like in group 1). Each of the institutions that were formed by and for the society based on the adat law, is believed to be the moral and legal source. ${ }^{11}$

The third group is the society that lives in villages near the cities. Although their way of life is already regulated by the state law, adat law still exists in certain aspects in the relationship between members of the society. Livelihood and professions of members of this society have become diverse, but farming is still the backbone of their economy; hence, the land holds an important role on the economic aspect. This keans that, the land is the center of farming activities, but in addition, the land could function as the most precious assets for investment.

The last group is the society that has developed into the rational culture stage. This society follows the modern way of life, where rationality is the basis of their life. Rational culture has become the source of science and technology, both are pushed to produce a life that is convenient and prosperous. To that end, their life order is governed by the rational legal norms which are sourced from the state law, including the utilization of land. The land is an asset for investment for their economic viability. In urban populations, they generally have formal education, and those who live there are investors who attempt to expand their business to villages or adat law society areas. They carry out investments under state law provisions relating to the business location license as well as land rights administration in which adat law society exists.

\section{B. Legal Pluralism on Land Law}

Observing the social structure with its each own cultural stage above, our society is a pluralistic society viewed from its legal culture. The word "pluralism", as concepted by Selo Soemarjan, refers to a condition where society is composed of various ethnicities that have varying cultures, while the concept of legal pluralism is developing among scholars until now. ${ }^{12}$

Indonesia (A Sociological Review)]" (speech delivered in Kraton Yogyakarta Sultanate in for the event of implementation of Rector of the Gadjah Mada University for awarding the commendation to Sri Sultan Hamengku Buwono XI), p. 4.

11 Ibid., hal 5

12 Soemardjan, Pluralisme Budaya, p. 3. Selo in defining the concept of pluralism refers to the variety of cultures of different ethnic groups that live in Indonesian soil. Culture itself, defined by him as all the results of ideals (among other in the form of technology and material culture). So that the law as referred in here is the form of manifestation of cultural element in his view. Thus the words of cultural pluralism include the legal pluralism. From this concept, it seems that Selo wanted to state the existence of cultural/ legal diversity from various social groups that different from one another but coexist within the territory of the Republic of Indonesia 
In a global perspective, legal pluralism is emphasized on the interactions between various legal systems (international law, state law, and local law), where in these interactions, each of the legal system either influence or avoid each other. This means that international agreements or treaties give an influence to national level policies which affects the policies on a local level. In this case, the state law used by investors faces the local law or local adat law. State policies on boosting investments in Indonesia, especially in the regions, conducted by Law No. 25 of 2007 on Investment (UU Penanaman Modal, hereinfafter referred to as UUPM). UUPM gives facility for investors (both for foreign and domestic) by exercising the simplification of licensing procedures and investment services. ${ }^{13}$ This government policy is based on the background of the economic development which drives the government, especially the regional government, to conduct enhancement measures of national/regional incomes through investment of land, including by means of land utilization in adat law society for modern businesses.

In the context of pluralism, the existence of the UUPM has created a latitude of interaction between the adat law society and modern society ${ }^{14}$ (urban society being represented by investors, both coming from the enterprises or the the government), where each party uses different legal systems in the same social field. This means that, natural resource (land) utilization in certain regions in the environment of adat law society, and then ruled by the state law, is also utilized by third parties (investors or private sector). The consequence is, there are situations where social interactions that occur between the adat law society and entrepreneurs are by both formal and informal ways. However, the occuring social interaction in the process of land utilization often takes place unpeacefully. Each party's misunderstanding on each of their own law regarding the use and utilization of natural resource is one the main causing factor of dissociative social interactions. These enterpreneurs, coming from the modern society that live in cities, and their life order, especially in the economic activities, are entirely based on the rational law that comes from the state law. It becomes an issue when those two different society with different cultures, in particular the context of implementation of legal norms regarding the use and utiliztion of the same land,

See also Sulistyowati Irianto, "Pluralisme Hukum Sebagai Suatu Konsep Dan Pendekatan Teoritis Dalam Perspektif Global [Legal Pluralism as the Concept and Theoretical Approach in the Global Perspective]," (paper presented in seminar on Pluralisme Hukum: Tantangannya bagi Pembentukan Sistem Hukum Nasional [Legal Pluralism: the Challenges for the Establishment of National Legal System] held by National Law Development Agency of the Ministry of Law and Human Rights and Faculty of Law Hasannudin University, Makassar, 1 - 2 May 2007). At the beginning, legal pluralism is defined as the co-existence between the various legal system in certain studied social fields. As noted by Sally Engle Merry, "is generally defined as a situation in which two or more legal system coexist in the same social field". In the initial paradigm, legal pluralism focuses on the explanation of how the diverse law jointly regulate certain areas of life, i.e. the existence of state law and adat law. This paradigm are then developed in the 90s, legal pluralism does not just show the diversity of law in the social field, but describe the legal systems that interact with each other. Related to this, Irianto cited the findings of Frans and Keebet von Benda Beckmann who conducted a research on the decisions of judges in courts of West Sumatera. The results is, mentioned that $80 \%$ of these decisions contained adat law, it shows that there has been the interplay between state law and adat law.

13 See Indonesia, Undang-Undang tentang Penanaman Modal (Law regarding Investment), UU No. 25 Tahun 2007, LN No. 67 tahun 2007, TLN No. 4724 (Law No. 5 of 2007, SG No. 67 of 2007), Art. 21.

14 Kurnia Warman and Hengki Andora, "Pola Hubungan Hukum dalam Pemanfaatan Tanah Ulayat di Sumatera Barat [Pattern of Legal Relationships in Communal Land Utilization in West Sumatera]," Mimbar Hukum 26, No. 3 (2014): 368. Actually, adat law also familiar with the use of hak ulayat by the external parties (who are not belong to adat law society). In this relationship, if the outsiders want to use hak ulayat, concerned party must as for the permission and pay secgnisi and/or levy to the community through the Chief of Adat society. 
claim that they are the legitimate rights holder of the land. Even though, each party has a justified basis of land rights according to each law.

With the condition of a pluralistic society, how can the state regulate the use and utilization of the land in Indonesia? The answer can be found if we return to basic principles of governance and utilization of any natural resources, including the land, that exist in the 1945 Constitution of the Republic of Indonesia, Article 33 paragraph (3) which states that: "The land, water and natural wealth contained within them are controlled by the State dan shall be utilised to increase the prosperity of the People." This means that state control is the authority of the state to decide the use, utilization, and the rights for natural resources in the scope of governing (regelen), administering or managing (bestuuren, beheren), and overwatching (tozichthouden) the use and utilization of natural resources, exercised for the prosperity of the people. ${ }^{15}$

Normatively, regulation regarding state control on natural resources was promulgated in the Basic Agrarian Law No. 5 of 1960 (Undang-Undang PokokPokok Agraria, hereinafter referred to as UUPA), on Article 2 paragraph (1). ${ }^{16}$ In the connnection to natural resources, the meaning of "controlled by the state" is translated as the means of giving the authority to the state as the organization of power of the Indonesian people in the highest level, ${ }^{17}$ among others, for governing; deciding the rights that can be held on (part of) land, water, and air space; legal relations between the people and the legal acts on land, water, and air space; and also exercising the allocation, utilization, provision, and preservation of the said natural resources.

From the explanation above, it can be concluded that: ${ }^{18}$ the characteristics and the scope of the meaning of the word "controlled" in Article 2 is aimed for public interests only. Regarding the land, the controlled land includes all kinds of land, with no exception, both owned by the private persons, legal persons, or land that not claimed by other parties. This means that, regarding the unclaimed land by private persons or legal persons, the state authority is wider and fuller than the claimed lands with certain rights. For the latter, the authority of state is limited to the content from the land rights. ${ }^{19}$ The state authority is also limited by the existing lands with hak ulayat of the adat law society. But, this limitation is only exercised if the hak ulayat still exists, and also as long as the hak ulayat does not conflict with national interests. 20

15 Darwin Ginting, Hukum Kepemilikan Hak Atas Tanah Bidang Agribisnis [Law on Land Ownership for Agribusiness Sector] (Bogor: Ghalia Indonesia, 2010), p. 61.

${ }^{16}$ Indonesia, Undang-Undang tentang Peraturan Dasar Pokok-Pokok Agraria (Law regarding Basic Agrarian Law), UU No.5 Tahun 1960, LN No.104 Tahun 1960 (Law No. 5 of 1960, SG. No. 104 of 1960), Article 2 paragraph (1) stated that: "Based on the provision Article 33, paragraph (3) of the Constitution and matters meant in Article 1, the earth, water and airspace, including the natural resources, contained therein are in the highest instance controlled by the State being and Authoritative Organization of the whole People." (hereinafter this law referred as UUPA)

17 See Ibid., Art. 2 paragraph (2) and General Elucidation point II (3)

${ }^{18}$ Arie Sukanti Hutagalung, "Konsepsi Yang Mendasari Penyempurnaan Hukum Tanah Nasional [Conceptions Underlying the Enhancements of National Land Law]" (professorial inauguration speech delivered at the Faculty of Law Universitas Indonesia, Depok, 17 September 2003), p. 17.

19 Ibid. Kekuasaan negara mengenai tanah baik yang sudah dihaki oleh seseorang atau badan hukum dengan suatu hak dibatasi oleh isi dari hak itu, artinya sampai seberapa negara memberikan kekuasaan kepada yang mempunyainya untuk menggunakan haknya, sampai di situlah batas kekuasaan negara tersebut. State authority over the land that are entitled already either by a person or legal entity is limited by the content of such rights, means that, to what extent the state grants the authority for them to exercise their right, that's where is the limits of state authority.

${ }^{20}$ Article 3 of UUPA, also see Husen Alting, "Penguasaan Tanah Masyarakat Hukum Adat ( Suatu Kajian 


\section{The Position of Adat Legal System within Indoneisan Legal System}

In the prespective of pluralism, the state recognizes the hak ulayat as the right to natural resources (land) of the adat law society. This recognition, realized through Article 18 of the 1945 Indonesian Constitution on its elucidation, especially in paragraph number II, which states the recognition and respect of regional characteristic diversity based on origins (translated as adat law) in Indonesia. ${ }^{21}$ In the implementation, this recognition of diversity of legal systems was abolished in Suharto's governance era by the enactment of Law No. 5 of 1979 regarding Village Goverment. Based on this law, the goverment uniformed all forms of village governance with reference to the Javanese village governance. Consequently, Nagari, Dusun, Marga, and other village goverments based on local adat law are abolished.

Twenty years later, after the reformation started in 1999, the Indonesian people demanded more democratic government on all levels. For that, the 1945 Indonesian Constitution is amended. With the amendment of the constitution, diversity of the adat law society is recognized and honoured again as stated in Article 18B paragraph (2) and Chapter VI regarding Local Government. ${ }^{22}$ This recognition is reiforced by Article 28I paragraph (3), which states that "cultural identity and rights of traditional society is regarded in line with the development of era and civilization". ${ }^{23}$

If we observe Article 18B paragraph (2) deeply, in relation with the recognition of the existence of the adat law society, it has less meaning. Because all the respect and protection to the adat law society, including their adat law, can only be exercised if

Terhadap Masyarakat Hukum Adat Ternate) [Land Tenure of Adat Law Society (A Study of Ternate Adat Law Society]," Jurnal Dinamika Hukum 11, No.1 (January 2011): 91. Recognition of hak ulayat of adat law society, shows the ability of state nationals, by adat/customary way to have control of the land collectively for the fulfillment of common interests, also the private right to land is allowed.

${ }^{21}$ Indonesian 1945 Constitution, Article 45 and part II of the Elucidation stated that: "In the territory of Indonesia there are approximately 250 self-governing regions (zelfbesturende landschappen) and village communities (volksgemeeschappen), such as the "desa" (village) in Java and Bali, the "nagari" in Minangkabau, the "dusun" and "marga" in Palembang and other social-adminstrative units. These regional units have their own indigenous social systems and thus may be considered as special regions. The Republic of Indonesia respects the status of the special regions and any government regulation on these regions shall have due regard to their hereditary rights." The existence of this article is inspired from Yamin's opinion, in a speech in the BPUPKI session dated May 28, 1945, he stated that: "nagari, village, and all adat law communion renewed with the rationalism and renewed over time time, (shall be) made as the feet of state organization as the bottom parts." Furthermore, he stated: "the ability and skill of the Indonesian nationals in sending state structure and land rights have appeared thousands of years ago, this can be seen in the composition legal communion as 21.000 villages in Java, 700 nagari in Minangkabau, and the formation of negeri sembilan in Malaya, as well as in Borneo, in the land of Bugis, Ambon, Minahasa, and so forth." The statement hinted that the adat law communion as mentioned above is the foundation of the Republic of Indonesia. As quoted by Yance Arizona, "Masyarakat Adat dalam Kontestasi Pembaharuan Hukum [Adat Community in the Contestation of Legal Reform]" (paper presented in Seminar Pemberdayaan Sosial Komunitas Adat: Upaya Peningkatan Efektifitas Pemberdayaan KAT Saat ini dan Pengembangan Ke Depan [Social empowerment of Indigenous Communities: Improving Effectiveness of KAT in Current and Future Development], held by National Planning and Development Agency, Jakarta, 15 May 2013), p. 2.

22 Indonesian 1945 Constitution, Article 18 B paragraph (2) stated that: "The State recognises and respects traditional communities along with their traditional customary rights as long as these remain in existence and are in accordance with the societal development and the principles of the Unitary State of the Republic of Indonesia, and shall be regulated by law.

${ }^{23}$ Until now there has been no explanation of the sense of cultural identity and rights of indigenous people. Is the traditional society same as the adat law society? Yet, however respect for cultural identity and rights of indigenous people must be in tune with the times and society. 
the state recognized the existence of the adat law society. This can also be observed in Article 3 of the UUPA, which gives the limitation to the state to regulate the land that adheres the hak ulayat on it, and the recognition and protection can be exercised as long as the hak ulayat existed, and does not contradict with national interests and higher regulations. ${ }^{24}$ This provision is actually a normative implementation of hak ulayat based on Article 2 paragraph (2), which is a delegation of "power from the state" with the limitations that are "merely necessary" and "not conflicting with national interests." ${ }^{25}$ As for the hak ulayat itself, it covers all the land under the area of concerned adat law societies, for both land rights that are already possessed by others or not. ${ }^{26}$

Based on Article 3 of the UUPA, the state exhibit dualistic attitude in providing the position of adat law in the state legal system. On one side, the adat law society and their traditional rights are respected, recognized and protected; on the other side, their existence is recognized with the certain limitations (conditional recognition). However, in implementing the condition of "existence", the state must be cautious, because this issue is very sensitive in nature.27 Conditional recognition on the enforceability of hak ulayat can be understood if we review the social condition of the Indonesian people at the time of the UUPA enactment. In the past, when the UUPA was enacted, a majority of the society were the subject of the adat law, ${ }^{28}$ but they also realized that in the Indonesian society structure there are growing communities that have developed in the direction of modern society, binding force of the adat law had weaken naturally, and in the end, the hak ulayat existence has ceased. The weakening of the adat law cannot be separated from the fact that the adat law society itself has changed drastically, and even vanished since the implementation of Law No. 5 of 1979 on Village Government. This implementation which has existed for 20 years destroyed the order of the adat law society until most of adat law institutions are faded.

With the explanation above, the conflict of communal land that occured as discussed in the previous section, cannot be separated from the legal policy of a state that still adheres to centralized law.29 Legal centralistic demands adhere to the law

${ }^{24}$ UUPA, Article 3, which stated that “... the implementation of the hak ulayat and rights similar to that of Adat-State's interests, based on die unity of the Nation, and shall not be in conflict with the acts and other regulations of higher level."

${ }_{25}$ Ibid., Article 2 paragraph (4), stated: "The implementation of above mentioned right of control by the State may be delegated to the autonomous region and adat Law Communities, if deemed necessary and not being in conflict with the National interest in accordance with the provisions of Government Regulation."

${ }^{26}$ Ibid., in general, boundaries of hak ulayat land can not be clearly defined.

${ }^{27}$ H. Abdurarahman, "Hukum Adat dalam Perundang-Undangan [Adat Law in the Legislations]" (paper presented at Seminar on Revitalization and Reinterpretation of Unwritten Values in Law-making and Legal Finding [Seminar Revitalisasi dan Reinterpretasi Nilai-Nilai Hukum Tidak Tertulis Dalam pembentukan dan Penemuan Hukum], Jakarta, 28-29 September 2005), p. 17; As quoted by Abdurrahman of the results of a symposium of UUPA and Position of Adat Law, held in Jakarta, recommendation of the symposium has given an appeal to the Government that the state should be careful in determining the presence or absence of hak ulayat, and the Government should not acting hastily in establishing the presence or absence of hak ulayat.

28 UUPA, General Elucidation Part III (1), UUPA reocgnized adat law in the provisions which stated that: "Inevitably, the new agrarian law should be consistent with the legal awareness of the common people. Since most Indonesian people adhere to adat (customary) law, the new agrarian law will also be based on the provisions of adat law, which is the indigenous law, with the latter being improved and adjusted to the interests of the people of a modern State which connects with the international community as well as to Indonesian socialism. ".

29 Yantje Laiaw, A. Suryaman Mustari Pide, Aminuddin Salle, Farida Patitinggi, "Adat Law in Designing of Land Law System," Journal of Law, Policy and Globalization 40 (2015): pp. 44. According to satjipto 
by all the Indonesian people, both who live in urban areas or adat law societies in remote areas. In the context of legal pluralism, the state adheres to weak pluralism. 30 It means that, in the relation between the state law and the adat law, the state law positions itself as the strongest legal source in the social field. After that, the adat law can be used as the legal source that accompanies the state law but only if the state law recognize its existence. As the higest level of the organizational body of the Indonesian people's power, the state has the authority to decide the use, utilization, and the right to natural resources in the scope of regulating (regelen), administering or managing (besuuren, beheren), and overseeing (tozichthounden) the use and utilization of natural resources. 31

\section{Social Impact from Conditional Recognition of Adat Law for Adat Law Society in Economic Development}

The existence of the investors for their participation in the development of the region, including the existence in the adat law society area cannot be separated from the implementation of Law No. 25 of 2007 on Investment. This law which has the spirit to encourage economic progress by inviting as many investors as possible, has been implemented by the state through the provision of facilities and amenities in delivering administration services and/or licensing services to obtain land rights (Article 21 item a). Land rights that are granted to investors may be extended and even renewed if the investors still need the respective land. As for land rights, it exists in the form of Hak Guna Usaha (HGU) which may be granted for 60 years (granted and extended in advance at a time) and can be renewed for 35 years, enabling the land rights for 95 years in total. Other rights over the land that can be granted to investors is Hak Guna Bangunan (HGB) for a period of 80 years and extended in advance for 50 years and can be renewed for 30 years. The last is, Hak Pakai which can be granted for 70 years, and can be broken down into the terms of 50 years given and extended in advance. Based on the state law, the government has the authority to issue land rights to investors in all regions of the country, including territories claimed by the adat law society.

The people, especially the adat law society, in fact does not reject the economic development that is being conducted by the government. From them, the most important thing is the real function of the development that could serve the community's livelihood. The development is perceived with hesitance, especially if the development alters or causes deviation from the adat law that exists in the concerned adat law society. Deviation from the adat law is not only perceived as a violation of adat norms, but also perceived as a violation for their religious norms, and therefore interferes their harmony of life that is respected by the society. Consequently, the development is interfered because the deviation from adat law

Rahardjo, when the adat law os confronted with national law, it will be exhausted and powerless. This is taking place as a result of the action of the legal experts who formulate the various law and regulations too normative without antropological and sociological awareness.

${ }^{30}$ Emil Ola Kleden, "Masyarakat Adat dan Proyek Pembangunan di Merauke: Medan Ketegangan Antara Berbagai Sistem Hukum [Adat Society and Infrastrcuture Projects in Merauke: Area of Tension between Various Legal System]," in Beragam Jalur Menuju Keadilan [Various Way towards Justice], ed., Marcus Colchester dan Sophie Chao ( Jakarta: Epistema Institute, 2012), p. 139. Weak legal pluralism, referring to the situation where the state law is in a position to overcome a variety of other legal systems in the semiautonomous space (as Kleden quoted the opinion of Griffith).

31 Ginting, Hukum Kepemilikan, p. 61 
causes conflict between societies that strongly adheres to the adat law and formalistic rules. The impact is, of course, it causes uncertainty of land rights which is probably perceived by both parties, if it is not resolved then it could causes an open conflict. An open conflict would arise when the sense of unrest is felt widespread but latent in the respective adat law society. This sense arises because of the social injustice perceived by communities that is caused by government policies towards the community or the domination of a faction in the society towards the adat law society. 32 This sense of unrest in the adat law society lead to a tense atmosphere, with the pressures that get higher over time until the conflict is unstoppable.

Regarding the continued effect from land conflicts, the author agrees with the opinion of Noer Fauzi Rachman which states that33 prolonged agrarian conflict creates a social-ecology crisis, where in this crisis, if it is not resolved by the government, could cause migration of village residents to new areas to obtain new land, or they would migrate and live in cities as the poor. This condition becomes new burden for urban societies, and could create new trouble. Furthermore, articulation of land conflicts could cause other conflicts. Based on the existing facts, the intensity and the quality of conflicts is on the rising trend.

These land conflict cases have occured in Sumatera, Kalimantan, Papua and Bima. In Sumatera, in particular Western Sumatera, as stated in the record by Lembaga Kerapatan Adat Alam Minangkabau (LKAAM), before the conflict arises between the adat law society and the company, there were already 29 cases of sako, pusako and communal land disputes which have yet to be settled until now, including the land dispute settlement of Nagari Lubuakkilangan with PT Semen Padang, which is known as the 'utilization of 412 hectares of land area'.34 Morning newspaper, Padang Ekspres, records that the conflicts of natural resources (land) in West Sumatera have involved almost 2.130 people of the adat law society with conflict areas that have already reached 27.000 hectares. 35 In South Kalimantan, based on the data delivered by Dwito Frasetiandy of WALHI South Kalimantan, agrarian conflicts in the period of 2012 - 2014 have reached 21 cases which involved 6.420 families with the area of conflict reaching 148.000 hectares. While the data from Konsorsium Pembaharuan Agraria (the Consortium of Agrarian Reform, KPA) in the period of $2004-2014$ states that 1.391 agrarian conflict cases have occured across Indonesia with the area

${ }^{32}$ Selo Soemardjan, “Disintegrasi Sosial dan Disintegrasi Negara [Social Disintegration and State Disintegration]" (paper presented at the Seminar Held by Faculty of Law Universitas Indonesia, 2000), p. 5. In a study conducted by the Yayasan Ilmu-Ilmu Sosial, revealed that the basic reason that makes people in the area easily explode in riots is a latent sense of unrest in the community in a long time. See also Zulheri Rajo Intan, "Pengeksploitasian Tanah Ulayat Berbasis Sistem Ekonomi Kerakyatan yang Berkeadilan Sosial dan Berkesinambungan [Exploitation of Communal Land based on Fair and Sustainable People's Economy]," Jurnal Hukum dan Pembangunan 46, no. 2 (2016): 125. Injustice is also felt when the exploitation of communal land for business purposes such as agriculture can not be benefitted by adat law society fairly.

33 Noer Fauzi Rachman, "Rantai Penjelas Konflik-Konflik Agraria yang Kronis, Sistemis, dan Meluas Di Indonesia [Clarifying Chain of Chnronic, Systematic, and Widespread Agrarian Conflicts in Indonesia]," Jurnal Bhumi 37, (April 2013): 10-11.

34 WALHI West Sumatera Chapter, https://groups.yahoo.com/neo/groups/walhisumbar/convesations/massage/663

35 Salim H. S. and Idrus Abdullah, "Penyelesaian Sengketa Tambang: Studi Kasus Sengketa Antara Masyarakat Samawa Dengan PT Newmont Nusa Tenggara [Mining Dispute Resolution: A Case Study of Dispute between the Peoples of Samawa With PT Newmont Nusa Tenggara]," Jurnal Mimbar Hukum 24, no.3 (October 2012): 477. Usually conflicts occur due to non-fulfillment of land compensation in accordance with the demand of adat law society, as has been investigated by the Iskandar Zulkarnain on gold mining in Pongkor, coal mines in South Kalimantan and tin mines in Bangka Belitung. 
of conflict reaching 5.711.396 hectares with more than 926.700 families that had to confront injustice and prolonged conflict.36 Even the Mesuji case has been a worst example of conflict escalation in terms of quality, meaning that the conflict itself has already escalated to war between groups to the point where it has caused casualties of several people that were invovled in said conflict.

\section{ADAT DISPUTE SETTLEMENT MECHANISM IN THE DRAFT LAW ON THE RECOGNITION AND THE PROTECTION OF THE RIGHTS OF ADAT LAW SOCIETY (RUU PPHMA)}

\section{A. Legal Analysis on Land Dispute Settlement based on RUUPPHMA}

The vacancy on the communal land dispute settlement mechanism which involves outsider parties have pushed adat law society activists to revive adat law within the state law. The RUUPPMHA regulates the dispute settlement mechanism on Chapter IV regarding Dispute Settlement Mechanism. ${ }^{37}$ Article 47 decided that in the event of a dispute, the dispute shall be settled in the Adat Court. If there is an objection to the Adat Court decision, the dispute can be appealed to the Supreme Court. It means that if the case involves outsider parties, the dispute can only be settled in the Adat Court. This is reaffirmed by Article 51 which states that the General Court (Pengadilan Umum) does not have the jurisdiction to settle disputes concerning adat law society, with the exception of serious criminal offense cases and special crimes, as stated in Article 44 paragraph (3). If there is a violation of competence to hear the case (for both internal dispute settlements between the adat law society, or with ousider parties), the decision would be null and void.

From the rules above, the dispute settlement mechanism contained in RUUPPMHA, in fact has been regulated despite the unclarity on the issue of electing judges and Adat Court procedures. The RUUPPMHA is only regulates in Article 48 concerning the requirements for the party who represent the adat law society and the witnesses that shall represent all the interests of the adat law society. While on the provision

${ }^{36}$ Sapariah Saturi, "Masyarakat Adat Vs Perusahaan Sawit Dominasi Konflik SDA di Kalsel [Adat Community vs. Palm Oil Plantation Companies Dominates Natural Resources Conflict in South Kalimantan]," http://www.mongabay.co.id/2014/11/14/masyarakat-adat-vs-perusahaan-sawit-dominasi-konflik-sdadi-kalsel/, accessed 14 April 2016.

37 RUU PPMHA Draft in Article 45 - 50 categorized disputes into three groups: 1) internal dispute; 2) inter-Adat law society dispute; and 3) the dispute between Adat Law Society and other parties.

a. Internal Disputes

Internal disputes within the Adat Law Society resolved through Adat Institutions (Lembaga Adat). Institute of Adat Institutions issues a decision as a result of the settlement of disputes. Dispute settlement within the Adat Law Society emphasized on Adat Institution Rulings as the product of dispute settlement in the area of public law, such as criminal case. In case of any objection against the decision of Adat Institution, the dispute is resolved through the Adat Courts. Adat Courts issues a decision as a result of the settlement of disputes. The award shall be final and binding.

b. Inter-Adat law society dispute

Inter-adat law society dispute settled by means of deliberation between adat institutions. In the case of deliberation not resolve the dispute, the dispute is resolved through Adat Courts. Adat Courts issue a decision as a result of the settlement of disputes. In the event of objection to the ruling, the dispute can be resolved at the Supreme Court.

c. The dispute between Adat Law Society and other parties

The other party referred in Article 47 paragraph (1) of RUU PPHMHA, among others, the Government, Local Governments, State Administration Officials, or other community members. Such dispute is resolved through Adat Courts. Adat Courts issue a decision as the result of the dispute settlement. In the event of objection to the Adat Court decision, the dispute can be resolved at the Supreme Court. 
on deciding judges, it simply referred in Article 49 that the Judges of Adat Court/ Supreme Court Judges in ruling matters relating to the adat law society shall take into account the adat law and traditions prevailing in the adat law society.

As for the basis of formation of Adat Court, is located on Article 44 paragraph (4) which states that "the Adat Court can be formed by the Adat Institution in stages from Adat Court in level of Regency/City up to the Provincial Level as High Adat Court (Mahkamah Tinggi Adat)." Adat Institution, based on the formulation of Article 1 point 8 , is an organization that grows along with the development of the adat law society whose purpose for existence is to organize, manage and resolve various problems of life according to the adat law. In other words, the Adat Institution is a form of adat government institution as referred to on Article 4 point (e), which contains the meaning of institutions that is grown and run by the adat law society through Adat Rules - Adat Chief, Penghulu Adat, Wali Adat, and others - to solve the problems regarding individual relations with others in communal life of the adat law society based on local traditions and adat.

For tiered Adat courts, the applicability of the adat law being limited in a regional scope where the adat law society lives should be questioned. Do Adat Courts have the same level following the structure of the State Court - tiered like the District Court, High Court and Supreme Court? This tiered level of Adat Court is not outlined on its elucidation part. While, if we read Article 47, we can see that there is a possibility for the parties to take the case to a Supreme Court level if the party does not agree with the ruling. In the content of said article, it does not mention whether the decision that will be reviewed by the Supreme Court should be a decision issued by which level of Adat Court or not. Because, if we follow the procedural logic that was done in the civil proceedings, then case reviews on the Supreme Court level should conducted after the party's request for examination of the decision issued by judges one level below the Supreme Court (High Court). If so, the hearing process in Adat Courts require a long time, considering the Draft Law does not set a specific time in every level of judicial proceedings, and this can cause uncertainty for both parties involved in disputes. This condition is not in line with the proceeding priciples which are fast, cheap and simple.

The emergence of Adat Courts in the RUU PPMHMA also produced a new problem that is the recognition of Adat Courts in Judicial Authorities in Indonesia. Because, with the enactment of Law No. 48 of 2009 on Judicial Power, Adat Courts are no longer known in within the state law. ${ }^{38}$

${ }^{38}$ Indonesia, Undang-Undang tentang Kekuasaan Kehakiman [Law regarding Judicial Powers], UU No. 48 tahun 2009, LN No. 157 tahun 2009, TLN No. 5076 (Law No. 48 of 2009, SG. 157 No. 2009), Article 18 stated that: "Judicial powers shall be exercied by a Supreme Court and the judicial bodies thereunder within the environment of General Courts, Religous Courts, Administrative Courts, and by a Constitutional Court." General Courts including: 1) District Court; 2) High Court; 3) Special Court, namely, Juvenile Court, Commercial Court, Human Rights Court, Corruption Crime Court, Industrial Relations Court, and Fisheries Court. Thus, it can be said that in the current legislation governing the judicial authorities, there is no recognition of Adat Courts. See Dominikus Rato, "Penyelesaian Sengketa Tanah Adat Dalam Perspektif Kearifan Lokal Pada Masyarakat Ngadu-Bhaga, kabupaten Ngada - NTT [Adat Land Dispute Resolution in the Perspective of Local Wisdom in the Ngadu-Bhaga Community, Ngada Regency, East Nusa Tenggara], Stanas Research Report term II, 2013. Prior to 1951, the parttern of traditional land dispute settlement conducted through the Adat Courts, which the process begins from the inner-tribe court by the Chief/Head of Adat society. If at the level the dispute is not resolved, then the dispute is brought to Swapraja Court. See also Gede Dewangga Prahasta Dyatmika, Iman Kuswahyono and Hamid Masykur, "Peran Kepala Adat dalam Penyelesaian Sengketa Tanah Nepang antara DesaAbdobala Dengan Desa Redovitena di Kecamatan Klubagolit - Abdonara- Flores Timur [The Role of Adat Chief in the Dispute Settlement of Nepang Land between the Village of Abdobala and Redovitena in Klubagolit District - Abdonara - East Flores]," Jurnal Hukum 
Law No. 48 of 2009 states that out-of-court dispute settlement is only limited to arbitration or alternative dispute settlement mechanism. Adat Court has long been abolished by the Emergency Law No. 1 of 1951, including Swapraja Court, as decided in Article 1 paragraph (1) of said law. ${ }^{39}$ The provision of this article is reaffirmed by the stipulation of Adat Court abolishment in Papua in 1970. ${ }^{40}$ Abolishment of these types of courts were carried out when the government was revamping the order of the courts in the frame of the Unitary State of the Republic of Indonesia. The existence of Adat Court at that time cannot be separated from the provision in Article 131 paragraph (6) of the Indische Staatsregeling (IS) and of old Article 75 of Regeerings Reglement (RR). Both articles decide that natives (pribumi), as long as they not subject themselves to the European Civil and Commercial Law, are subject to their own adat law. Consequently, the colonial government still impose a special court reserved for the natives based on the adat law rules, and with the procedural rules other than the HIR as long as it does not contradict with the general principles of justice. This means that, if the law contradicts with common sense of justice, then the judge can set aside the adat law. ${ }^{41}$ As for the meaning of the Adat Court based on Article 75 of the RR, is a State Court (landraad) for natives who examine cases based on the adat law. This means that this kind of court only examines the dispute between the members of the adat law society that are not subject to the European law, so the proving mechanism is not subject to the provisions of the HIR. ${ }^{42}$

So, what about the formation of the Adat Court in RUUPPMHA? In the light of the discussion above, it can be concluded that the Adat Court 'can' be formed by Adat institutions. This provision shows the source of authority for court administration that is derived from the adat/local law system used by the concerned community. Since the authority was derived from the local adat law system, then the implementation

Universitas Brawijaya (February 2015): 1-16. The role of Adat Chief of in dispute resolution is to lead and conduct deliberations to reach agreement so that the decision can be accepted by all parties. However, in research conducted by Gede et. al., showed that the dispute can be resolved by state law when customary law is not effective anymore. As happened in the Nepang village - East Flores.

39 Indonesia, Undang-Undang Darurat tentang Tindakan-Tindakan untuk Menyelenggarakan Susunan, Kekuasaan, dan Acara Pengadilan Sipil [Emergency Law on Measures for Organizing Structure, Power, and Procedures of Civil Court], UU Darurat No. 1 tahun 1951 (Emergency Law No. 1 of 1950), Article 1 paragraph (2) stated that: "gradually, over time time, will be determined by the Minister of Justice the abolishment of:

a. Swapradja Court (zelfbestuurrechtspraak) in the former East Sumatera State, former West Kalimantan Recidency, and the former East Indonesian States, except for the Religious Court if the said court according to living law is a part of Swapraja Court.

b. All Adat Courts (Inhemse rechtspraakin rechtsteeks bestuurd gebied), except for Religious Courts if the said court according to the living law is an independent part of Adat Court."

${ }^{40}$ Abdurrahman, Hukum Adat, p. 13.

41 Soepomo, Bab-Bab tentang Hukum Adat [Chapters on the Adat Law] (Jakarta: Pradnya Paramita, 1987), p. 33-34. In his writing, Soepomo also explains that the provisions regarding the phrase "shall not be contrary with the common sense of justice" which is not exist in Article 131 IS. It doesn't mean that the Judge no longer be able to question whether a rule of adat law contradicts with the condition of humanity. The judge has the authority according to his function, even obliged to consider whther the exisitng adat law rules relating to faced issues, still in line with the social reality in relation to the development of new situation in the society.

42 See Hilman Hadikusuma, Peradilan Adat di Indonesia [Adat Courts in Indonesia] (Jakarta: CV Miswar, 1989), p. 38-39. Adat courts are state courts (landraad) that in conducting the hearing process using adat law (as long as it does not contradict with the general principles of justice, according to Art. 75 paragraph (3) and (6) RR), or it means that the Judge in giving the consideration is not only bound by the legislations, but also should consider the living law in the society that is adat law. Other than than, in the process of proving, judge is not bound by procedural rules of HIR (RIB) S.1941 No. 44. 
of dispute settlement mechanism is based on the rules of adat law or tradition that has been maintained and accepted by the local community for a long time from generation to generation. In this case, local wisdom becomes the source and basis of the conflict in social interactions within the community; hence, the ruling issued by the Adat Courts do not decide who is losing or winning, but it decides what is best for both parties in the dispute by pointing to the principle of win-win solution.

In relation to Article 47 paragraph (2) which states that in case of an objection for Adat Court decisions, disputes can be settled in the Supreme Court level, and this raises another question: can a judicial institution, which operate under the authority derived from the adat law system, have the jurisdictional authority to access the State Court institution (Supreme Court) whose authority is derived from the state's legal system? Reading the terms of this article, it seems that the legislator of RUU PPHMHA is aware of the possibility of unenforceable Adat Court decisions, even if it is possible that one party might not accept such decision.

To address these possibilities, it seems that the lawmakers seek to affirm the relationship between the Adat Courts with the Supreme Court in the context of the operation of Adat Courts in Indonesia. The question is whether this relation is legally possible or not. The problem is, in Law No. 48 of 2009 regarding Judiciary Powers, it states that the judicial power is conducted by a Supreme Court and the Courts thereunder are the General Courts, Religious Courts, Military Courts, Administrative Courts, and the Constitutional Court. So, Adat Courts are not the part of the judiciary institutions that exercise judiciary powers. The consequence is, Adat Courts cannot pass its ruling to the Supreme Court to be examined (judex juris). For that, if the lawmakers of this draft still want to construct the relationship between the Adat Courts and the Supreme Court, there should be provisions for the Adat Court decisions to be enforced by the Decree of District Court, so that the decisions can be executed effectively. In that case, if there are parties who object the intended execution of the decision, the parties concerned may file the opposition to the District Court in question, then the decision can be forwarded to the Chamber of Adat Civil in Supreme Court.

Regarding the concept of Adat Courts as introduced by RUU PPMHA above, it must be clear if the Adat Court as referred to in this Draft is the same as the adat institution that functions as adat court? The term "Courts", basically can be conducted with proceeding system (deliberation) to settle the case within the court or out of court. If it is linked with the adat law, it can be called an Adat Court. ${ }^{43}$ The said court can be conducted by members of society, head of family, head of adat society, or head of village. In this case, the dispute settlement mechanism carried out by adat proceeding corresponds with the characteristics of the adat law society who emphasizes the value of harmony in the relationships between the member, based on the values that live in accordance with spiritual nature and social life of members of the communion. ${ }^{44}$ In this kind of Adat Court, the mechanism used is materialized in the form of deliberation, not for finding out who is right or wrong, but rather to attempt to find the best way to keep the harmony in the concerned adat law society. ${ }^{45}$

\footnotetext{
43 Hilman Hadikusuma, Pengantar Ilmu Hukum Adat Indonesia [Introduction to the Indonesian Adat Law] (Bandung: Mandar Maju, 2003), p. 247

44 Bushar Muhammad, Asas-Asas Hukum Adat [Principles of Adat Law] (Jakarta: Pradnya Paramita, 2002), p. 9.

${ }^{45}$ Currently there are areas that have been revitalized Adat Court, as in the sense of adat court by deliberation, but still limited to disputes between members of adat law society or among the adat law society.
} 
If the above concept is intended by the RUU PPMHA, it would be appropriate if a dispute is only internal dispute or disputes among the adat law society. This is consistent with the concept of adat law as a non-statutory law - not been written or not written in positive law clause. Adat law also applies in a socio-geographical manner, where the adat law applies only to the scope of certain adat law societies within specific adat society regions. However, if one of the parties do not use the adat law but other legal systems that differ from the adat law, i.e. disputes between the adat law society and other parties - the Local Government, Investor/Entreprenur, or other community members, it is difficult to use the adat law-based dispute settlement mechanism for disputes that involve two different legal system.

In the context of legal pluralism, the question is, which legal system is to be used by the judge when deciding such cases? The provisions of Article 49 of the RUU PPHMHA which obliges judges to observe the adat law and customs, implies the existence of partiality of the judges on one legal system. In fact, in deciding cases, other than observing prevailing customs or adat law, the judges are also bound by policy or other applicable legislations in Indonesia, particularly laws related to the cases. This provision actually reduces the principle of justice that must be upheld by judges, and the judge shall decide to accomodate the interests of the adat society and the public interests or between the adat society and the private sector.

When there are disputes with outsiders, in the judicial process, there will be a problem of evidence. While the adat society only has sociological evidence (de facto), the outsiders have evidence based on state law (de jure). Furthermore, the execution of the decision provided in Article 50 that the decision of Adat Courts as referred to Article 45 paragraph (4), Article 46 paragraph (3), and Article 47 paragraph (2) shall be implemented by the adat law society and/or District Court. This provision is confusing and also shows the weakness of the Adat Courts. This indicates that the Adat Courts have no necessary tools to execute the decision. This is a weakness of Adat Courts that could lead into legal uncertainty, because the outcome may not be executed without the assistance of the District Court.

The last question mentioned above, seems to not have any answer in the RUU PPMHA. The legislator of the RUU PPMHA is supposed to realize that at present, the adat law society has developed, social and economic relations occur not only within the community itself but also with other parties who are bound by other legal systems. In solving the problems caused by the interaction in such relationships, this draft law shows the provisions that have the spirit to protect and respect the rights of the adat law society, but not feature the concept of Adat Courts, its basic formation, and its clear procedural law.

In the pluralistic state, it is necessary for clarity in giving the concept of dispute settlement mechanism so that the outcome can be accepted by the parties. Some weaknesses in concepts, authority and procedure of Adat Courts contained within this draft law might be why the draft has not been passed by the Parliament (DPR) until now, given its drafting has begun since 2009.

For instance, in Papua, by Law No. 21 of 2001 on Special Autonomy for Papua Province. As for the meaning of Adat Courts provided in this law, is a court of peace in adat law society that have the authority to hear civil and criminal cases among the member of the society. In Article 50, it stated that:

(1) Judicial power in Papua shall be exercised by the Courts in accordance with the legislation.

(2) In addition to the judicial authority as referred to in paragraph (1), adat court is recognized in certain adat law society. 


\section{B. Recognition and Protection of the Rights of Adat Law Society to Land in the Agrarian Ministerial Regulation}

\section{Agrarian Minister/Head of National Land Agency Regulation No. 5 of 1999 regarding Dispute Resolution Guidelines for Communal Land Rights of Adat Law Society}

Factually, the adat law society have settled and conducted their activities in an area within a long period of time, where the process of management and ownership are based on the adat law, so it is difficult to prove the ownership in a juridical-formal manner. In the adat law-based evidence proving, such mechanism is exercised with "material justification," that is a fact according to material evidence that can be considered as something that is true, or true in fact, de facto proof. Such method of proving is enough for the adat law society, given every transfer of rights under the adat law is exercised in a "clear and cash" (terang dan tunai) manner. This means that "clear" is the act of transfer of rights carried out before the head of the adat society or the elders publicly, so that the community know about the transfer of rights. By being conducted in a "clear" manner, third parties who feel that they have the ownership on said transferred rights can challenge the transactions, but if there are no objections from third parties, the transfer of rights have occured. As for "cash", this means that any act of transfer of rights must be paid immeadiately at the time the act was commited publicly. Even if it turns out that the payment can not be made in full, it does not diminish the validity of the transfer. Subsequent payments are considered as an act of payable accounts. The terms of the validity of transfer with "clear and cash" have become the basis of legal certainty for the new rights owner.

Meanwhile, the verification process under the state law is conducted through a mechanism held in the General/Civil Courts. The verification is not enough to be carried out just in a de facto manner; it also has to be featured by de jure proof, or formal proof. This means that the "truth" can be achieved according to the formal verification which can be considered as something that is true or factually true according to the statutory provisions in force. Based on Articles 23, 32, and 38 of the UUPA, land registration is a strong evidence concerning the transfer of rights and cease of rights due to time exhaustion. The said provisions can be interpreted if the rights holder face a lawsuit over the land, then in the process of proving the validity of proprietary rights can only be recognized by their certificate of land rights. Certificate of land rights is strong evidence of ownership as long as it is not proven otherwise. Therefore, in such conditions, settlement of communal land dispute is more difficult to achieved given each party will prove the ownership by their respective legal systems.

In response to these conditions, in 1999 the government issued Regulation of the Minister of Agrarian Affairs (Permenag) No. 55 of 1999 regarding Dispute Resolution Guidelines for Communal Land Rights of the Adat Law Society. The birth of this regulation is based on the consideration that in reality, at the time, many areas with existing lands within the environment of the adat law community, which the maintenance, control, and use is based on the rules of the local adat law and recognized by respective members of the adat law society as their communal land, and in various regions raise various problems regarding the existence and tenure of the communal land.

Hak ulayat or communal land rights is defined by this Permenag as the authority of the adat law society members to take advantage of natural resources, including 
land, that arise both outwardly and inwardly by hereditary and uninterrupted manner between the adat law society and the area concerned (Article 1 point 1 ). The implementation of all hak ulayat is as long as it still exists and the state recognizes its existence if it meets the requirement under Article 2, among others: 1) there is a group of people who are bound by the adat law order; 2) there are lands which are used to fulfill their necessities of life; and 3) there is an existing adat law order that is governing, controlling, maintaining, and using communal land that obeyed by the people.

From the provisions of Article 2, the existence of hak ulayat lands still depend on the recognition by the state first. For that, there must be a reseearch and determination to assert that the three requirement as set forth in Article 2 are met. The party who is authorized by the Permenag to conduct research and determination is the Local Government with participating experts of adat law, the adat law society in their respective areas, NGOs, and agencies that manage resources (Article 5). If it is then decided from the study that the three requirements are fulfilled and valid, then the existence of communal land is stipulated in the respective Local Government Regulation and its territorial limit is declared in the base map of the land registration by affixing a cartographic sign and, if possible, having the map describe the boundaries and record it in the land registration list.

The provisions of Article 5 has become important if the areal boundaries of the adat law society land is clear, then anyone who wants to use the hak ulayat or cooperate can easily identify those who should be contacted and invited to the negotiations. In addition, the adat law society which has a certificate of the hak ulayat land will be granted tenure by the state under Article 2 paragraph (2). In said article, it was mentioned that if the leasehold (Hak Guna Usaha, HGU) derived from the hak ulayat of the adat law society have expired or ceased based on the provisions of the legislation, the land is released back as the hak ulayat of the adat law society. Even if the rights are be extended, aforementioned HGU shall be based on the new agreement between the adat law society and the HGU holder. This provision is filled with legal protection for the adat law society, because so far the UUPA is silent on this issue. In fact, before the enactment of this regulation, even for expired HGUs, the land remains as the state's land. ${ }^{46}$

However, the recognition and protection of the hak ulayat as described above is restricted if the land which at the time of enactment of the Local Government Regulation, is already owned by the individuals or legal entities (Article 3). In that article, it was stated that the investigation of the existence of communal land is not carried out in the areas where the land has been assigned rights under the UUPA. This provision could create a new problem and because of the restriction, the adat law society could no longer ask for the recognition of communal land rights on the land in which it has already gained other rights under the UUPA. This can be understood because the capital invested by the entrepreneur is also not small, so they also need the certainty of investment. However, looking from the perspective of the adat law society, this provision can be perceived as the tool to extinguish the hak ulayat itself. This provision can be the opportunity for the re-emergence of land conflicts between

${ }^{46}$ The said provision has been adopted by Law No. 18 of 2004 on Plantations which stated that: "In the case of required land is communal land rights of adat law society, which exists in reality and precedes the granting of rights to the Applicant, the Applicant shall conduct consultations with the adat law society who holds the hak ulayat and concerned land rights holder to obtain an agreement on the handover of land and compensation". 
the adat law society and investors, when the claim of the adat law society is denied for access to justice.

In the light of the discussion above, it can be concluded that the Permenag which consists of 6 Articles which intends to set the guidelines for resolution of dispute related to hak ulayat of the adat law society, but on contrary this Permenag has yet to provide dispute settlement mechanism on such issues. The Permenag just assumes that the root cause of conflict between the adat law society and the ousiders (investor) only comes from the existence of the hak ulayat from the adat law society. For that, the solution is set through enacting the Local Government Regulation.. By enacting the Local Government Regulation, the conflict assumed can be avoided. Meanwhile, there is no provision that provides a better solution for the conflicts that occur when said regulation establishes certain areas that have been claimed as communal land which has been owned by individuals or legal entities, as well as the ongoing conflicts because it is a high chancethat the area currently planted by plantation companies are the land previously managed by the adat law society. Regulatory vacancy on such land dispute settlements enables agrarian conflicts in the community to continue.

\section{Minister of Agrarian and Spatial Planning/Head of National Land Agency Regulation No. 9 of 2015 on Procedures for Establishing Communal Land Rights of the Adat Law Society and Communities in Certain Regions}

Unlike the previous Permenag, this regulation, as reffered to in the title's wording is clearly intended to set the procedures for establishing communal land rights of adat law societies and communities in certain regions. The thing to consider is that the Indonesian land law recognizes communal rights and is similar to that of an adat law society, as long as they still exsist in fact. In addition, there are the rights of the people who control the land for a certain long period of their livelihood that must be protected in order to realize the use of land for the greater prosperity of the people.

There are two new things introduced in this ministerial regulation. First, rather than using the term "hak ulayat", the new regulation is now using the term of communal rights (hak komunal). Second, the subject of regulation is no longer just an adat law society, but also the general public who reside in certain regions. Regarding the definition of communal rights, in Article 1 point 1, it is mentioned that communal rights on land is the common ownership on land of a adat law society or common ownership of land which given to the communities in forest or plantation areas. While the meaning of specific areas is forest or plantation areas. In this regulation, it is stated that the adat law society or communities in certain specific areas can apply for land rights. As for the land rights granted to the two mentioned communities, it is a communal right (Article 4). To that end, it is required to have prior recognition from the respective adat law society and from communities outside the adat law society itself. For the adat law society, the recognition for their existence can be granted if (Article 3 paragraph (3)): 1) the communities are in the form of a communion (paguyuban); 2) there is an existence of adat law authorities; 3) clear adat law territory; and 4) the existence of their institutions and legal instruments that are still adhered to.

Meanwhile, the recognition of the existence of communities in a specific area is given if (Article paragraph (2)) it meets the requirements, namely: 1) existing community that has physically controlled the land for at least 10 consecutive years or more; 2) existing activities of harvesting resources for daily life; 3) the claimed area have become the source of people's livelihood; and 4) exsiting social and economic 
activities are integrated with lives of the people. Furthermore, to determine if the requirements are met, the process of identification, verification, and field inspection should be carried out by a team formed by the regent or governor (depending on the location of the land area, wheter in one regency or accross two more regencies), as stipulated in Article 6 to Article 11. In the case that the team found the existence of adat law society or communities in specific regions, then the team will report these findings to the regent or the rovernor to be given communal rights land for the adat law society or communities in specific regions. The said decision is then delivered to the Head of Office of Land Affairs or the Head of Regional Office of the National Land Agency (BPN) to be registered at the respective Office of Land Affairs (Article 12 and 13) to obtain the certificate of communal land rights.

With the Communal Land Certificate, the adat law society may cooperate with third parties in accordance with the provisions of the legislation and the agreement between the parties. For the people who are in forest areas whose rights have been released, they are required to work and cultivate the land by themselves and must maintain their sustainability. If they are located in the plantation area, after the Communal Land Certificate is handed, they are required to arrange it for themselves in the form of co-operations, partnerships, unit that is a part of a village or other form of community. One more obligation that must be met is the utilization of land that shall be adjusted with type of plant/commodity that is grown or cultivated by the plantation companies concerned.

This Ministerial Regulation has broadened the prearranged subject, it does not not only affect the adat law society, but also affects the general public who has controlled specific areas such as forests or plantation areas for harvesting for at least 10 years. The said provision shows that the policy makers want to make people outside of the adat law society able to access the recognition and protection by the government, considering that many land dispute cases also occur among people who have managed and worked on plantation land with investors. However, this provision should be implemented carefully in appointing the parties as the communal rights owner. Since the wording "controlled" has various meaning, the issue is whether or not the controlled area obtained with the release of rights by certain party or on what basis can they control the area. It is possible that the land controlled by said community is also located in the area of communal land of adat law societies, but for certain reasons, the concerned land is then managed and utilized by them. This could lead to a new conflict because the outsiders who have migrated to the adat law society and have occupied their land for 10 years can claim the land as their own. In this case, the government is simplifying the problems regarding the recognition of communal land rights.

Based on the description above, it can be said that this regulation does not regulate the dispute settlement related to communal land, but is only limited to the prevention of conflict through the recognition of adat law societies and communities in certain areas, and granting communal rights with the certificate issued by the BPN. Unfortunately, the last Permenag raises potential conflict between the adat law societies and communities existing in certain areas. However, if we examine further, through the issuance of the Local Government Regulation as stipulated in the Permenag, it is expected that the adat law society and communities in certain regions could be directly involved in the economic development of the region. Until now, from 365 indigenous ethic groups that are officialy recognized by the General Directorate of Remote Adat Communities of the Ministry of Social Affairs, only 11 adat groups 
have been appointed in the Local Government Regulation regarding communal land. From these 11 groups, only 1 hak ulayat of Baduy community has clearly established their boundaries. Therefore, from 11 groups, only 1 area, that is Baduy's communal land that can be processed by the BPN for certification. ${ }^{47}$ For the rest, their hak ulayat cannot be registered, and it will be diffucult for them to defend their rights when dealing in negotiations with investors, and even harder for communities other than the concerned 11 groups.

\section{ALTERNATIVE DISPUTE SETTLEMENT OF COMMUNAL LAND RIGHTS OF ADAT LAW SOCIETY: WIN-WIN SOLUTION FOR BOTH PARTIES (INVESTOR AND ADAT LAW SOCIETY)}

In the current pluralistic legal condition, the challenge in resolving disputes becomes important when two legal systems are facing each other. The challenge is to clarify the jurisdiction of the various legal systems mentioned before, especially when there is a dispute between members of the adat law society and external parties (government or investors); which law will prevail for both parties? Or, can it be prevented when one of the parties involved choose the most profitable form of settlement?

The emergence of the dispute settlement mechanism between the adat law society with third parties (investors) through Adat Courts as reintroducted by the RUU PPMHMA raises a new issue that is the legal recognition of Adat Courts in the judiciary powers of Indonesia. Since the enactment of Law No. 48 of 2009 on Judiciary Powers, the judicial branch is only exercised by the Supreme Court and the courts that under it which are the General Courts, Religious Courts, Military Courts, Administrative Courts, and a Constitutional Court (Article 18). Based on this article, the chances for the recognition of Adat Courts as introduced in the RUU PPHMA is closed.

But, if we refer to the 1945 Constitution of the Republic of Indonesia, the opportunities for court regulations outside the Judiciary Powers Law is possible. Article 24 paragraph (3) of the 1945 Constitution states that "other institutions whose functions have a relation with the judicial powers shall be regulated by law." The phrase "shall be regulated by law" contains the meaning that the regulation concerning Adat Law does not necessarily have to be regulated by specific laws regarding the courts (Judiciary Powers Law), but it can be regulated in other sectoral laws. In several regions, the Local Governments have taken the effort to revitalize respective Adat Courts. For instance, in West Sumatera, Bali, Central Sulawesi, and Papua. Unfortunately, from all Adat Courts that exist in the region, the existence of Adat Courts are only officialy recognized by law in Papua, based on the Law No. 21 of 2001 regarding Special Autonomy of the Papua Province (Article 50). ${ }^{48}$

47 Director of Spatial Planning and Land Affairs, Ministry of National Planning and Development/National Planning and Development Agency, "Kebijakan Nasional Penetapan Tanah Adat/Ulayat [National Policy on Decision of the Communal Land Rights" (paper presented at the workshop on Realisasi Hak Atas Tanah dan Rumah di daerah tertinggal [Realization of the Right to Land and Housing in underdeveloped areas], Jakarta, 15 January 2014.

48 Indonesia, Undang-Undang tentang Otonomi Khusus bagi Provinsi Papua (Law regarding Special Autonomy for Papua Province), UU No. 21 tahun 2001, LN No. 135 Tahun 2001 (Law No. 21 of 2001, SG No. 135 of 2001), in Article 50 stated that: 1) judicial power in Papua province exercised by the Court in accordance with laws and regulations; 2) in addition to the judicial authorities as referred in paragraph (1) adat courts is recognized in certain adat community. 
Adat Courts as referred to in the Papuan Special Autonomy Law is the court of peace in the environment of the adat law society which have the jurisdiction to hear civil and criminal cases among the concerned community. Such Adat Courts have existed for a long time in the adat law society and known as the term "adat hearing" or "adat meeting" ("sidang adat" or "rapat adat") in the phrase that vary according to the local language, and it is realized in the form of deliberation between the elders. The purpose of ruling in adat hearing is not to find out who is right or wrong, but rather as the means of finding the best way to maintain harmony in the communities.

Adat Courts for the adat law society can function as the fortification of adat law to ensure that the law and local wisdom can be maintained. Examples of cases that represent this situation is the Baduy community who have their adat law that is binding and maintained until now by their community, incluidng their adat law and adat court. ${ }^{49}$ In the context of this paper, it should be a concern that Adat Courts' authority in handling internal disputes related to adat civil disputes or adat offense, needs to be strengthened. This can be done by emphasizing Adat Court's presence through the stipulation by the governor or regent, as it has been done by the Papuan government and other provincial goverments such as West Sumatera with the appointment of Nagari that acts as an adat proceeding.

Under different circumstances, when there is an adat dispute involving a third party (investors), the use of Adat Courts as a means of dispute settlement mechanism is difficult to implement, since it involves two different legal systems. In the interaction between the two legal systems, there is a possibility for these two systems to support each other, but it is also possible for them to erase each other, or there might be a friction between them. In reality, the decision of the Adat Courts cannot automatically be executed. This can be seen from cases where the decision of the Adat Court is challenged to the state court, or in the sense that the external party have two simultaneous trials (Adat Courts and State Courts), as it has happened in the execution of the Decision of Adat Proceeding of Kapus Hulu District - Central Kalimantan. ${ }^{50}$

\footnotetext{
${ }^{49}$ National Law Development Agency (BPHN), "Peluang Peradilan Adat Dalam Menyelesaikan Sengketa Antara Masyarakat Hukum Adat Dengan Pihak Luar [Opportunities of Adat Courts in Resolving Disputes between Adat Law Society and External Parties]," Final Research Report, Center for National Legal System Research and Development, November 2013. Sadim case (2005), a homicide carried out to the resident of Baduy community who become his employer in unconcious state. The killings occured because sadim have violated adat law prohibition of wood cutting due to by order of his employer, Sadim also did not attend the Ngaseuk Serang ceremony, which is first rice cultivation ceremony mandatory for all citizens of inner Baduy. The following morning, Sadim suddenly awakened from his sleep with a red face and shaking. He feels that there is a tiger about to pounce on him, so then unconciously, he thrust the knife in all directions including to his employer. These actions, considered by Baduy elders Jaro Daniahn occured because Sadim violated adat law. Consequently, Sadim received two separate punishment, that is based on adat law and state law. For the homicide case, he was sentenced to seven months in prison by District Court of Lebak, also detained for 40 days by Adat Court before his trial. However, during the adat detainment, he died due to stress and mental disorder. See also the case of adat violations involving external party, namely TransTV. This case occured when TransTV took several footages in inner Baduy territory secretly, and then they broadcast it. Although, from a long time there were prohibition for taking any footage for any intention in inner Baduy area. Based on adat hearing, TransTV is required to do a "acara adat pemulihan" or customary remedy ceremony, so called ngabokoran. Ngabokoran is a traditional ceremony for asking apologize to the ancestors (karuhun), and for means of cleansing so that the balance is revived.

50 See the court decisions, among others, Decision of Palangkaraya District Court No. 87/Pdt.G/2010. PN.PL.R which ajudicates the civil dispute between Tahau B. Tibas - a farmer in Kapuas Hulu Disrict (Claimant I), Siner (Claimant II), Pdm. Zakaria - a pastor and chairman of NGO Forum Keluarga Sejahtera, Central Kalimantan against PT. Dwie Warna Karya (Respondent I), the Governor of Central Kalimantan c.q. Secre-
} 
Learning from the case handled by the Adat Courts above revealed ineffective position and role of Adat Courts regarding natural resources (land) disputes. The Decision of Adat Proceeding of Kapuas Hulu District shows that this institution is not capable when dealing with large companies, especially in the case of natural resources (land) utilization. It also shows the conflict of logics between informal law (adat law) and formal law (state law). Thus, if the Adat Courts are used as the communal land dispute settlement mechanism, the main thing to concerns is the minimum competence of Adat Courts. The challenges of this competence are mainly related with knowledge (not only legal knowledge of adat law, but also state law), leadership, and impartiality. These challenges are difficult to defeat, given the structure and cultural diversity within society. As explained in the earlier part of this paper, several (or most) portion of the society strongly persists their customs including their traditions, so formal law (state law) is not used by them because it is unknown to them. There are two possibilities to explain this alienation to state law, which are: 1) these societies are geographically and cuturally isolated so that their knowledge of formal law is hampered; and 2) from the government side, the lack of infrastructure and human resources that attributes to formal law causes this legal system to be unable to be understood well or perhaps even inaccessible for the local community.

Therefore, if the settlement of communal land disputes involving external parties (investors) persists to be settled in Adat Courts in the upcoming law, there should be a clearer averment regarding the relation between the Adat Courts and the District Court/Supreme Court in the related legislations. Another alternative in order to find a form of dispute settlement mechanism of communal land with investors is to encourage the acceleration of the establishment of the Agrarian Court. In the implementation, so that the decision can be accepted by both parties, the membership of the Panel of Judges/Examiner should come from the member of the adat law society itself, represented by the indigenous figures, elements of the government, academemicians, or experts in the related field. It is also important that the approach used in resolving disputes should be using not only a juridical approach, but also a sociological approach. Formal juridical approach alone will not achieve effective results. The state law simply cannot be expected to solve land disputes that are so complex, because the issue of land disputes does not only involve the law alone but

tary of the Province (Co-respondent II), also Charman of Dayak Adat Council, Central Kalimantan Province (Co-respondent III). This lawsuit filed by the Claimants which Claiman I own, control, and maintain a plot adat land - with the length of 1000 meters, width of 500 meters, an area of 50 hectares, located on either sideof Sepan river, creeks of Pari, Village of Sei Hanyo (called Pantung/Jeluntung road), Kapuas Hlu District, Kapuas Regency, Central Kalimantan. This case arose when in 2008, the exitence of adat land location is damaged due to eviction by PT. Dwie Warna Karya, palm oil plantation companies that obtained Location Permit from the Regent of Kapuas Decree No. 377 of 2006 dated 9 September 2006 concerning Granting Location Permit to the PT. Dwie Warna Karya for the purpose of Oil Palm Plantation Area. Settlement efforts through adat hearing have been conducted with the decision of: PT. Dwie Warna Karya must pay for the violation of adat law Rp10.000.000 (ten million rupiahs), compensation for damage for the amount of Rp1,1 billion (one billion one hundred million rupiah), that must be paid to Tahau B. Tibas, also settlement fees for amount of Rp5.000.000 (five million rupiahs) to Damang, Head of Adat Society of Kapuas Hulu District. In the implementation of the decision, PT. Dwie did not obeyed the Decision rendered by adat hearing exercised by Mantir Karapaan Adat and Damang Kepala Adat concerned. Then the claimant filed the civil court hearing under the basis of tort. Unfortunately, the Decision of District Court rejects the claim with stating that the claim can not be accepted (niet ontvantkelijkverklaard), due the the lawsuit contains error in persona as the grounds of disqualification. This case shows how the implementation of adat court ruling still leaves the issue relating to execution. Although, in Central Kalimantan Provincial Regulation No. 16 of 2008, and Kapuas Regency Regulation No. 5 of 2001, stated that Decision of Kerapatan Mantir Adat in adat proceeding shall be final and binding on the parties to the dispute. 
also involves the social system and the culture of the local adat law society, meaning that in the hearing process, the Judges do not only examine the laws and regulations related to the dispute, but also the socio-legal aspect of the dispute. In other words, the Agrarian Court Judges in deciding a case shall prioritize material justice and produce a decision that promotes a win-win solution.

\section{V.CONCLUSION}

\section{A. Conclusion}

Until now, the government has had no regulations on the dispute settlement between the adat law society and the investors related to the utilization and ownership of natural resources (land). Currently, existing regulations are in the form of a guidline to address the settlement of issues of the adat law society in the perspective framework of conflict prevention with external parties or investors through recognition from the state, which are issued by the Minister of Agrarian Affairs in two regulations: Minister of Agrarian Affairs Regulation No. 5 of 1999 and Minister of Agrarian and Spatial Affairs No. 9 of 2009.

The emergence of a new thought on Adat Courts in the RUU PPMHA is a new hope for the adat law society who perceived that the state policy related to natural resources often causes troubles for their life which still depend on the access of natural resoruces that have been controlled by investors. But it should be realized that there are weaknesses concerning the RUU PPMHA, especially on the provision related with the process, authority, and the supervision of said law for its role of dispute settlement meachanism. This would cause legal uncertainty and uncomprehensive handling of adat-related disputes, and would also cause unrest for the people. In the meantime, land conflicts still occur, so land related dispute handling through the mechanism that can accepted by both parties is necessary.

\section{B. Suggestions}

1. Adat Courts need to be supported by strenghtening its position in the national legal system. For that, it requires the reaffirmation of the relationship between the Adat Courts with the Domestic Courts/Supreme Court. Or, given the many weaknesses in the RUU PPHMHA, it needs to be considered to accelerate the establishment of special laws dealing with cases of communal land disputes through the Agrarian Courts with different characteristics of the General Court, where the decision of the Agrarian Court shall promote deliberation to aim a win-win solution decision. To that end, the judge is obliged to pay attention to the socio-legal aspects of the dispute in making the decision;

2. As a community empowerment of indigenous participation in the economic development in the region, the establishment of adat region in the framework of the Local Government Regulation regarding the Adat Law Society needs to be accelerated nationally. For that, the Local Government should coordinate with the Ministry of Agrarian Affairs as an effort to accelerate the establishment of the adat law society region in the area; and,

3. Given that the ability of the community to negotiate with investors have not been adequate, the adat law society needs to be assisted in negotiating. To that end, appointed assistants should be able to provide consultation and advoacy 
related with the drafting of cooperation agreement with investors. This form of assistance can be conducted by involving universities, and developing civil law clinic programs as a means of legal assistance to the local communities. 


\section{Bibliography}

\section{Legal Documents}

Indonesia. The 1945 Constitution of the Republic of Indonesia

---. Undang-Undang Darurat tentang Tindakan-Tindakan untuk Menyelenggarakan Susunan, Kekuasaan, dan Acara Pengadilan Sipil (Emergency Law on Measures for Organizing Structure, Power, and Procedures of Civil Court). UU Darurat No. 1 tahun 1951 (Emergency Law No. 1 of 1950).

---. Undang-Undang tentang Kekuasaan Kehakiman (Law regarding Judicial Powers). UU No. 48 tahun 2009, LN No. 157 tahun 2009, TLN No. 5076 (Law No. 48 of 2009, SG. 157 No. 2009).

---. Undang-Undang tentang Otonomi Khusus bagi Provinsi Papua (Law regarding Special Autonomy for Papua Province). UU No. 21 tahun 2001, LN No. 135 Tahun 2001 (Law No. 21 of 2001, SG No. 135 of 2001).

---. Undang-Undang tentang Penanaman Modal (Law regarding Investment). UU No. 25 Tahun 2007, LN No. 67 tahun 2007, TLN No. 4724 (Law No. 5 of 2007, SG No. 67 of 2007).

---. Undang-Undang tentang Peraturan Dasar Pokok-Pokok Agraria (Law regarding Basic Agrarian Law), UU No.5 Tahun 1960, LN No.104 Tahun 1960 (Law No. 5 of 1960, SG. No. 104 of 1960).

Palangkaraya District Court. "Decision No. No. 87/Pdt.G/2010.PN.PL.R.”

\section{Books}

Ginting, Darwin. Hukum Kepemilikan Hak Atas Tanah Bidang Agribisnis [Law on Land Ownership for Agribusiness Sector]. Bogor: Ghalia Indonesia, 2010.

Hadikusuma, Hilman. Pengantar Ilmu Hukum Adat Indonesia [Introduction to the Indonesian Adat Law. Bandung: Mandar Maju, 2003.

---. Peradilan Adat di Indonesia [Adat Courts in Indonesia]. Jakarta: CV Miswar, 1989.

Kleden, Emil Ola. "Masyarakat Adat dan Proyek Pembangunan di Merauke: Medan Ketegangan Antara Berbagai Sistem Hukum [Adat Society and Infrastrcuture Projects in Merauke: Area of Tension between Various Legal System]." In Beragam Jalur Menuju Keadilan [Various Way towards Justice], edited by Marcus Colchester dan Sophie Chao. Jakarta: Epistema Institute, 2012.

Muhammad, Bushar. Asas-Asas Hukum Adat [Principles of Adat Law]. Jakarta: Pradnya Paramita, 2002.

National Law Development Agency (BPHN), "Peluang Peradilan Adat Dalam Menyelesaikan Sengketa Antara Masyarakat Hukum Adat Dengan Pihak Luar [Opportunities of Adat Courts in Resolving Disputes between Adat Law Society and External Parties]," Final Research Report, Center for National Legal System Research and Development, November 2013.

Soekanto, Soerjono dan Mustafa Abdullah. Sosiologi Hukum dalam Masyarakat [Sociology of Law in Society]. Jakarta: Rajawali Pers, 1987. 
Soepomo. Bab-Bab tentang Hukum Adat [Chapters on the Adat Law]. Jakarta: Pradnya Paramita, 1987.

\section{Articles}

Abdurarahman, H. "Hukum Adat dalam Perundang-Undangan [Adat Law in the Legislations]." Paper presented at Seminar on Revitalization and Reinterpretation of Unwritten Values in Law-making and Legal Finding [Seminar Revitalisasi dan Reinterpretasi Nilai-Nilai Hukum Tidak Tertulis Dalam pembentukan dan Penemuan Hukum], Jakarta, 28-29 September 2005.

Alting, Husen. "Penguasaan Tanah Masyarakat Hukum Adat ( Suatu Kajian Terhadap Masyarakat Hukum Adat Ternate) [Land Tenure of Adat Law Society (A Study of Ternate Adat Law Society]." Jurnal Dinamika Hukum 11, No.1 (January 2011): 87-98.

Arizona, Yance. "Masyarakat Adat dalam Kontestasi Pembaharuan Hukum [Adat Community in the Contestation of Legal Reform]." Paper presented in Seminar Pemberdayaan Sosial Komunitas Adat: Upaya Peningkatan Efektifitas Pemberdayaan KAT Saat ini dan Pengembangan Ke Depan [Social empowerment of Indigenous Communities: Improving Effectiveness of KAT in Current and Future Development], held by National Planning and Development Agency, Jakarta, 15 May 2013.

Director of Spatial Planning and Land Affairs, Ministry of National Planning and Development/National Planning and Development Agency. "Kebijakan Nasional Penetapan Tanah Adat/Ulayat [National Policy on Decision of the Communal Land Rights." Paper presented at the workshop on Realisasi Hak Atas Tanah dan Rumah di daerah tertinggal [Realization of the Right to Land and Housing in underdeveloped areas], Jakarta, 15 January 2014.

Gede Dewangga Prahasta Dyatmika, Iman Kuswahyono dan Hamid Masykur. "Peran Kepala Adat dalam Penyelesaian Sengketa Tanah Nepang antara Desa Abdobala Dengan Desa Redovitena di Kecamatan Klubagolit - AbdonaraFlores Timur [The Role of Adat Chief in the Dispute Settlement of Nepang Land between the Village of Abdobala and Redovitena in Klubagolit District - Abdonara - East Flores]." Jurnal Hukum Universitas Brawijaya (February 2015): 1-16.

Hutagalung, Arie Sukanti. "Konsepsi Yang Mendasari Penyempurnaan Hukum Tanah Nasional [Conceptions Underlying the Enhancements of National Land Law]." Professorial inauguration speech delivered at the Faculty of Law Universitas Indonesia, Depok, 17 September 2003.

Intan, Zulheri Rajo. "Pengeksploitasian Tanah Ulayat Berbasis Sistem Ekonomi Kerakyatan yang Berkeadilan Sosial dan Berkesinambungan [Exploitation of Communal Land based on Fair and Sustainable People's Economy]." Jurnal Hukum dan Pembangunan 46, no. 2 (2016): 120-148.

Irianto, Sulistyowati. "Pluralisme Hukum Sebagai Suatu Konsep Dan Pendekatan Teoritis Dalam Perspektif Global [Legal Pluralism as the Concept and Theoretical Approach in the Global Perspective]." Paper presented in 
seminar on Pluralisme Hukum: Tantangannya bagi Pembentukan Sistem Hukum Nasional [Legal Pluralism: the Challenges for the Establishment of National Legal System] held by National Law Development Agency of the Ministry of Law and Human Rights and Faculty of Law Hasannudin University, Makassar, 1 - 2 May 2007.

Rachman, Noer Fauzi. “Rantai Penjelas Konflik-Konflik Agraria yang Kronis, Sistemis, dan Meluas Di Indonesia [Clarifying Chain of Chnronic, Systematic, and Widespread Agrarian Conflicts in Indonesia]." Jurnal Bhumi 37, (April 2013): 1-14.

Safitri, Myrna A.“Jalan Ketiga Menuju Keadilan: Berbagai Upaya Memperluas Akses Terhadap Keadilan Pegelolaan sumber daya Alam Dalam Pembauran Hukum Di Indonesia [The Third Way Towards Justice: Efforts Expanding Access to Justice Natural Resources Management In Law Reform in Indonesia]." Paper presented at the national seminar on Membangun Politik Hukum Sumber Daya Alam Berbasis Cita Hukum Indonesia [Building a Politics of Law of Natural Resources based on Rechtsidee of Indonesia], Semarang, Diponegoro University, 15 April 2015.

Salim, H. S. and Idrus Abdullah. "Penyelesaian Sengketa Tambang: Studi Kasus Sengketa Antara Masyarakat Samawa Dengan PT Newmont Nusa Tenggara [Mining Dispute Resolution: A Case Study of Dispute between the Peoples of Samawa With PT Newmont Nusa Tenggara]." Jurnal Mimbar Hukum 24, no.3 (October 2012): 477-488.

Soemarjan, Selo. "Disintegrasi Sosial dan Disintegrasi Negara [Social Disintegration and State Disintegration]." Paper presented at the Seminar Held by Faculty of Law Universitas Indonesia, 2000.

---. "Modernisasi: Arti dan Konsepnya dalam Pembangunan Indonesia [Modernization: Its Meaning and the Concept in the Development of Indonesia]." in Pokok-Pokok Pikiran Selo Soemardjan, edited by Desiree Zuraida and Jufrina Rizal. Jakarta: Pustaka Sinar Harapan, 1993.

---. "Pluralisme Budaya di Indonesia (Suatu Tinjauan Sosiologis) [Legal Pluralism in Indonesia (A Sociological Review)]." Speech delivered in Kraton Yogyakarta Sultanate in for the event of implementation of Rector of the Gadjah Mada University for awarding the commendation to Sri Sultan Hamengku Buwono XI.

Warman, Kurnia and Hengki Andora. "Pola Hubungan Hukum dalam Pemanfaatan Tanah Ulayat di Sumatera Barat [Pattern of Legal Relationships in Communal Land Utilization in West Sumatera]." Mimbar Hukum 26, No. 3 (2014): 367-379.

Yantje Laiaw, A. Suryaman Mustari Pide, Aminuddin Salle, and Farida Patitinggi. "Adat Law in Designing of Land Law System." Journal Of Law, Policy and Globalization 40 (2015): 40-46.

\section{Websites}

Rakyat Merdeka. "Kritis, Permintaan Lahan Industri 1.000 Ha Per Tahun [Critical, the Demands of Industrial Area Reached 1.000 hectare annualy]." http:// www.kemenperin.go.id/artikel/4137/Kritis-Permintaan-Lahan-1.000- 
Ha-Per-Tahun. Accessed 8 September 2015.

Hariyanti, Dini. “2015-2019, Kebutuhan Lahan Kawasan Industri capai 3.353 hektar [2015-2019, Needs for Land for Industrial Area Reaches 3.353 hectare]." http://industri.bisnis.com/read/20140905/257/255383/2015-2019kebutuhan-lahan-kawasan-industri-capai-3.353-hektar-. Accessed 8 September 2015.

Investor Daily. "Kawasan Industri Butuh Lahan 10 Ribu Ha [Industrial Area Needs 10.000 hectares of Land]." http://www.kemenperin.go.id/artikel/4702/ Kawasan-Industri-Butuh-Lahan-10-Ribu-Ha. Accessed 8 September 2015.

Ministry of Agriculture of the Republic of Indonesia. "Rencana Strategis Kementerian Pertanian tahun 2015-2019 [Strategic Action Plan of the Ministry of Agriculture 2015 - 2019]" http://www.pertanian.go.id/file/ RENSTRA 2015-2019.pdf. Accessed 3 February 2016.

Suprapto, Hadi and Erik Hamzah. "Sengketa Tanah Mencapai 12 Ribu Kasus [Land Dispute Cases Reach 12 Thousand]." http://nasional.news.viva. co.id/news/read/463821-sengketa-tanah-mencapai-12-ribu-kasus. Accessed 12 March 2016.

Saturi, Sapariah. "Masyarakat Adat Vs Perusahaan Sawit Dominasi Konflik SDA di Kalsel [Adat Community vs. Palm Oil Plantation Companies Dominates Natural Resources Conflict in South Kalimantan]." http://www. mongabay.co.id/2014/11/14/masyarakat-adat-vs-perusahaan-sawitdominasi-konflik-sda-di-kalsel/. Accessed 14 April 2016. 